\title{
Caring for Cancer Patients during Corona Pandemic- (COVID-19)-A Narrative Review
}

\author{
Sree Karthik Pratapa ${ }^{1}$ Sourya Acharya ${ }^{1} \quad$ Sai Spoorthy Mamidipalli ${ }^{2}$ Amol Andhale ${ }^{1}$
}

\author{
${ }^{1}$ Departments of Medicine, Jawaharlal Nehru Medical College, Datta \\ Meghe Institute of Medical Sciences (Deemed to be University), \\ Wardha, Maharashtra, India \\ 2Departments of Psychiatry, Jawaharlal Nehru Medical College, \\ Datta Meghe Institute of Medical Sciences (Deemed to be \\ University), Wardha, Maharashtra, India
}

Address for correspondence Dr. Sree Karthik Pratapa, Junior resident, Department of Medicine, Jawaharlal Nehru Medical College, Datta Meghe institute of medical sciences, Wardha, Maharashtra, 442001, India (e-mail: sk.pratapa@gmail.com).

\section{South Asian J Cancer 2021;10:19-22.}

Dr Pratapa

$$
\begin{aligned}
& \text { Keywords } \\
& \text { - cancer } \\
& \text { - coronavirus } \\
& \text { - COVID-19 }
\end{aligned}
$$



Background Coronavirus disease 2019, the third pandemic of 21st century which has brought the whole world under panic, is caused by severe acute respiratory syndrome coronavirus 2 (SARS-CoV-2), a zoonotic beta coronavirus sharing phylogenetic, genomic similarities with SARS virus and Middle East Respiratory Syndrome virus.

Specific Concerns Cancer patients are at double the risk than normal patients since these patients are at immunocompromised state. WHO guidelines advice the patients to plan only emergency hospital visits only till the pandemic persists. Should meet patient/visitors in a well-ventilated room or outdoors and maintain at least $2 \mathrm{~m}$ distance between the visitor/patients. It also encourages the patient to refill the prescribed medications in well advance and to stay physically active, if possible.

Discussion The World Health Organizations' isolate, trace, test, treat policy needs to be followed to protect these high-risk patients from this global pandemic.

\section{Introduction}

Coronavirus disease 2019 (COVID-19), a new pandemic, is caused by severe acute respiratory syndrome coronavirus 2 (SARS-CoV-2), a zoonotic beta-coronavirus. This was the third zoonotic coronavirus outbreak in the first two decades of the 21 st century that spreads by the human-to-human transmission causing global health concern within a short duration. Based on genome sequencing, 2019 novel coronavirus is about $89 \%$ identical to bat SARS-like CoVZXC21, 82\% identical to human SARS-CoV, and about 50\% to the Middle East Respiratory Syndrome coronavirus (MERS-CoV). ${ }^{1,2}$ Scientific advances from the SARS and MERS outbreaks can provide valuable insight into rapid understanding and control measures of the current pandemic.

\section{Epidemiology}

The epidemiological characteristics of SARS-CoV-2, SARS, and MERS have been compared in - Table $1 .{ }^{2}$

DOI https://doi.org/10.1055/s-0040-1721292 ISSN 2278-330X.

How to cite this article: Pratapa S. K, Acharya S, Mamidipalli S. S, et al. Caring for Cancer Patients during Corona Pandemic-(COVID19)-A Narrative Review. South Asian J Cancer 2021;10(1):19-22.

\section{Overview of COVID-19 Outbreak}

SARS-CoV-2 is a novel coronavirus causing the outbreak of a pandemic viral infectious disease termed as coronavirus disease 2019 (COVID-19). It was first detected in Wuhan, China in December 2019 (Centers for Disease Control and Prevention, March 21, 2020; World Health Organization [WHO], January 12, 2020). Since then, the virus has spread to over 205 countries infecting about 13,47,803 people, of which 74,807 died globally; In India, there are about 4,426 confirmed cases of which 114 deaths were recorded according to WHO by April 7, 2020. These numbers are changing every minute and incidence and mortality figures will be higher subsequently by the time this article is published.

According to WHO, the new coronavirus, SARS-CoV-2 so far has an average R0 (contagion metric) between 2 and 2.5 which means a person infected with COVID-19 can pass it to more than two people which is higher than seasonal flu (R0 at 1.3), Influenza A virus subtype H1N1 (R0 at 1.2 and 1.6), and Ebola (R0 at 1.6 and 2) but less than SARS (R0 at 4) and MERS (R0 at 2.5 and 7.2). ${ }^{16}$

\section{(C) 2020. MedIntel Services Pvt Ltd.}

This is an open access articlepublished by Thieme under the terms of the Creative Commons Attribution-NonDerivative-NonCommercial-License, permitting copying and reproduction so long as the original work is given appropriate credit. Contents may not be used for commercial purposes, or adapted, remixed, transformed or built upon. (https://creativecommons.org/ licenses/by-nc-nd/4.0/)

Thieme Medical and Scientific Publishers Pvt. Ltd., A-12, 2nd Floor, Sector 2, Noida-201301 UP, India 
Table 1 Epidemiology characteristics of COVID-19, severe acute respiratory syndrome, and middle-east respiratory syndrome

\begin{tabular}{|l|l|l|l|}
\hline & COVID-19 & SARS & MERS \\
\hline Origin location & Wuhan, China & Gaungdong, China & Jeddah, Saudi Arabia \\
\hline Total cases & $12,79,722^{+3}$ & 8,096 & 2,229 \\
\hline Total deaths & $72,614^{3}$ & 774 & 79 \\
\hline Health care worker cases (\%) & 3.8 & 21 & 18.6 \\
\hline Reproductive number & $3.28^{2}$ & $3.0^{4}$ & $<1.0^{5}$ \\
\hline Incubation period (days) & $4.75-6.4^{6}$ & $4.0^{7}$ & $4.5-5.2^{8}$ \\
\hline Serial interval (days) & $2.6-7.5^{9}$ & $8.4^{10}$ & $12.6^{11}$ \\
\hline CFR (\%) & $3.85^{2,12}$ & $9.6^{13}$ & $35.5^{14}$ \\
\hline CFR with co morbidities (\%) & $73.3^{12}$ & $46.0^{15}$ & $60^{15}$ \\
\hline
\end{tabular}

Abbreviations: CFR, case-fatality rate; COVID-19, coronavirus disease 2019; MERS, Middle East respiratory syndrome; SARS, severe acute respiratory syndrome.

\section{Oncological Determinants of COVID-19}

Cancer patients are at higher risk since that these patients are more susceptible to SARS CoV-2 virus causing COVID-19, than individuals without cancer. These individuals are in an immunosuppressive state caused by malignancy and anticancer treatments, such as chemotherapy, targeted therapy, and immunotherapy. National Health Service, England warned that certain groups are particularly vulnerable to serious illness if they are infected with SARS-CoV-2. These groups include individuals who are undergoing active chemotherapy or radical radiotherapy for lung carcinoma and cancer of blood or bone marrow. Blood cancers often directly compromise the immune system, so patients are at high risk compared to other active cancer patients. In patients with lung carcinoma with prior history of smoking, data have shown that in smokers, there is an increased gene expression of angiotensin-converting enzyme 2, the binding receptor for SARS CoV-2 due to significant tobacco consumption; and hence smokers are more susceptible to COVID-19 compared to nonsmokers. According to an analysis of Italian patients published in March 2020, 20\% of the total patients who died from COVID-19 disease in Italy had active cancer. ${ }^{17}$

As per the report of the WHO-China Joint Mission on COVID-19, cancer patients had an estimated twofold increased risk of COVID-19 than the general population. The study results suggested that hospital visits were a likely contributing factor to the increased incidence in cancer patients. The potential risk factors of older age, comorbidities, and smoking history could help oncologists to identify patients with poor prognosis at an early stage. ${ }^{18} \mathrm{~A}$ study by Cai et al, suggests that patients of COVID-19 included in the study had preexisting conditions including diabetes (6.4\%), hypertension (12.8\%), cardiovascular diseases (3.7\%), liver diseases (2.7\%), malignancy (1.4\%), and others (3.7\%). ${ }^{19}$

\section{Prevention of COVID in Patients with Cancers}

Precautions to prevent spread of SARS-Cov-2 in cancer patients must be the priority since that these patients are at increased risk than the normal population. Cancer patients must be thoroughly counseled about the signs and symptoms and need to approach the doctor if any of the symptoms appear, train about social distancing, and the need of the use of masks to protect themselves. The patient must continue their treatment unless they are in close contact with the patient with COVID-19 or relative symptoms. A comprehensive work-up should be performed in patients when they present with fever or other symptoms related to infections of COVID-19 as there is no specific guidance about COVID-19 testing in cancer patients.

- Electivesurgeries/radiotherapy/immunosuppressivetherapy/ planned stem cell transplantation should be rescheduled or modified by the oncologist, keeping an individualize risk/ benefit assessment in mind.

- In posttransplant patients, extra care and restriction of visitors must be encouraged to avoid the potential exposure.

- Cancer patients on regular follow-up can avoid hospital visits and potentially resort to telemedicine in case of need.

\section{General Protection Steps for Cancer Patients and Cancer Care Delivery Challenges among COVID As Suggested by WHO March 20, $2020^{20}$}

- Handwashing with alcohol-based hand rub or soap and water.

- Cover mouth with a tissue while coughing and sneezing, dispose of the tissue, and wash hands.

- Avoid frequent touching face with unclean hands.

- Regular cleaning and disinfection of frequently touched objects and surfaces.

- Avoiding close contact with people-keep more than $1 \mathrm{~m}$ distance between you and others.

- Avoid crowded spaces, especially less ventilated areas and indoors.

- Avoid contact with anyone who is ill with a cough, fever, or difficulty in breathing.

- Do not share objects that touch your mouth-such as cups, spoons, bottles.

- Do not shake hands. Practice social distancing. 


\section{Added Protection to Be Taken in Cancer Patients by Care Givers}

As per WHO guidelines, ${ }^{20}$ advice the patients to plan hospital visit only in case of an emergency and avoid routine consultations in person till the pandemic persists.

- Should meet patient/visitors in a well-ventilated room or outdoors.

- Should maintain at least $2 \mathrm{~m}$ distance between the visitor/ patients.

- Encourage the patient to refill the prescribed medications in well advance.

- Advice the patient to stay physically active, if possible.

\section{Discussion}

COVID-19, the new pandemic, is the major health concern in the world right now. Many countries even the one with the best medical facilities are having a tough time managing the pandemic and keeping their citizens safe. The biggest concern at this moment for any country is to avoid the spread of the disease and limit the mortality since that the treatment protocols are yet at the level of trails and no proven treatment has been formulated. At this juncture, every country is striving to adopt WHO isolate, test, treat, and trace policy, ${ }^{21}$ where countries must isolate, test, treat, and trace to avoid the resurfacing of epidemic once the restrictions are lifted.

As discussed, cancer patients are at high risk due to their prior immunosuppressive state and other comorbidities causing them to be more susceptible to the on-going disease. Surviving this pandemic needs a combined effort from the patient and the caregiver to avoid the patient from being exposed to the infective environment. The caregivers and patients should observe that these patients at higher risk should isolate themselves from unnecessary exposure, do fact checks from the myths circulating on social media (-Table 2), ${ }^{22}$ and maintain proper hygiene habits following WHO guidelines; test/seek doctors attention only if they are exposed to COVID-19-positive/suspected patient and are symptomatic.

\section{Conclusion}

Today, the world has turned into a global village where each country is interdependent, and these pandemics remind us time after time that we need to self-assess our interventions, whether they are relevant to changing environment and present scenario. It is time for everyone to think globally and act locally to ensure that the interventions are appropriate and right in actions such that this globe remains sustainable for centuries to come.

\section{Funding \\ None.}

\section{Conflicts of Interest}

There are no conflicts of interest.
Table 2 Myths and facts regarding coronavirus disease 2019 circulating on social media

\begin{tabular}{|l|l|}
\hline $\begin{array}{l}\text { Myths/ } \\
\text { misinformation }\end{array}$ & Facts \\
\hline $\begin{array}{l}\text { Only older patients } \\
\text { are at risk of } \\
\text { COVID-19. }\end{array}$ & $\begin{array}{l}\text { People with age }>60 \text { y with preexisting } \\
\text { conditions such as diabetes, heart prob- } \\
\text { lems are more vulnerable, but young } \\
\text { people can also get infected. }\end{array}$ \\
\hline $\begin{array}{l}\text { Spraying alcohol } \\
\text { or chlorine kills the } \\
\text { coronavirus. }\end{array}$ & $\begin{array}{l}\text { Though these are used as disinfectants, } \\
\text { spraying these on skin would not kill the } \\
\text { virus. }\end{array}$ \\
\hline $\begin{array}{l}\text { Drinking huge } \\
\text { amounts of } \\
\text { water flushes out } \\
\text { coronavirus. }\end{array}$ & $\begin{array}{l}\text { There is no scientific evidence as such to } \\
\text { prove the statement. }\end{array}$ \\
\hline $\begin{array}{l}\text { Thermal scanners can } \\
\text { detect early coronavi- } \\
\text { rus infection. }\end{array}$ & $\begin{array}{l}\text { Thermal scanners are effective in meas- } \\
\text { uring skin temperatures to detect fever, } \\
\text { an early symptom of COVID-19 but not } \\
\text { for COVID-19 screening. }\end{array}$ \\
\hline $\begin{array}{l}\text { Specific medicine } \\
\text { use in the treatment } \\
\text { or prevention of } \\
\text { coronavirus. }\end{array}$ & $\begin{array}{l}\text { There is no proven medicine that can } \\
\text { prevent or provide any specific treat- } \\
\text { ment for virus infection. }\end{array}$ \\
\hline $\begin{array}{l}\text { Vaccines against } \\
\text { pneumonia can } \\
\text { protect against coro- } \\
\text { navirus infection. }\end{array}$ & $\begin{array}{l}\text { The vaccine against pneumonia (pneu- } \\
\text { mococcal and Hemophilus influenzae B } \\
\text { vaccine) does not provide any protection } \\
\text { against SARS-CoV-2. }\end{array}$ \\
\hline Abrevions:coviD-19, coronavirs
\end{tabular}

Abbreviations: COVID-19, coronavirus disease 2019; SARS-CoV-2, severe acute respiratory syndrome coronavirus 2 .

\section{References}

1 Chan JF, Kok KH, Zhu Z, et al. Genomic characterization of the 2019 novel human-pathogenic coronavirus isolated from a patient with atypical pneumonia after visiting Wuhan. Emerg Microbes Infect 2020;9(1):221-236

2 Liu Y, Gayle AA, Wilder-Smith A, Rocklöv J. The reproductive number of COVID-19 is higher compared to SARS coronavirus. J Travel Med 2020;27(2):taaa021

3 World Health Organization. Novel coronavirus (2019-nCoV) situation report-51 2020. World Health Organization; 2020. Available at: https://www.who.int/docs/default-source/coronaviruse/situation-reports/20200407-sitrep-78-covid-19. pdf? Accessed Apr 07, 2020

4 Bauch CT, Lloyd-Smith JO, Coffee MP, Galvani AP. Dynamically modeling SARS and other newly emerging respiratory illnesses: past, present, and future. Epidemiology 2005;16(6):791-801

5 Bauch CT, Oraby T. Assessing the pandemic potential of MERS-CoV. Lancet 2013;382(9893):662-664

6 Yang Y, Lu Q Liu M, et al. Epidemiological and clinical features of the 2019 novel coronavirus outbreak in China. medRxiv 2020; (DOI: 10.1101/2020.02.10.20021675.

7 Lessler J, Reich NG, Brookmeyer R, Perl TM, Nelson KE, Cummings DA. Incubation periods of acute respiratory viral infections: a systematic review. Lancet Infect Dis 2009;9(5):291-300

8 Park JE, Jung S, Kim A, Park JE. MERS transmission and risk factors: a systematic review. BMC Public Health 2018;18(1):574

9 Nishiura H, Linton NM, Akhmetzhanov AR. Serial interval of novel coronavirus (2019-nCoV) infections. Int J Infect Dis 2020;93(2020):284-286 
10 Lipsitch M, Cohen T, Cooper B, et al. Transmission dynamics and control of severe acute respiratory syndrome. Science 2003;300(5627):1966-1970

11 Cowling BJ, Park M, Fang VJ, Wu P, Leung GM, Wu JT. Preliminary epidemiological assessment of MERS-CoV outbreak in South Korea, May to June 2015. Euro Surveill 2015;20(25):7-13

12 Guan WJ, Ni ZY, Hu Y, et al; China Medical Treatment Expert Group for Covid-19. Clinical characteristics of coronavirus disease 2019 in China. N Engl J Med 2020;382(18):1708-1720

13 WHO. Summary of probable SARS cases with onset of illness from November 1, 2002 to July 31, 2003. Available at: https:// www.who.int/publications/m/item/summary-of-probablesars-cases-with-onset-of-illness-from-1-November-2002-to31-July-2003

14 WHO. WHO MERS global summary and assessment of risk. Available at: https://www.who.int/csr/disease/coronavirus_ infections/risk-assessment-august-2018.pdf?ua=1. Accessed August 18, 2018

15 Badawi A, Ryoo SG. Prevalence of comorbidities in the Middle East respiratory syndrome coronavirus (MERS-CoV): a systematic review and meta-analysis. Int J Infect Dis 2016;49: 129-133

16 Zhao S, Lin Q, Ran J, et al. Preliminary estimation of the basic reproduction number of novel coronavirus (2019-nCoV) in
China, from 2019 to 2020: a data-driven analysis in the early phase of the outbreak. Int J Infect Dis 2020;92:214-217

17 Burki TK. Cancer guidelines during the COVID-19 pandemic. Lancet Oncol 2020;21(5):629-630

18 Zhou F, Yu T, Du R, et al. Clinical course and risk factors for mortality of adult inpatients with COVID-19 in Wuhan, China: a retrospective cohort study. Lancet 2020;395(10229):1054-1062

19 Cai Q Huang D, Ou P, et al. COVID-19 in a designated infectious diseases hospital outside Hubei Province, China. Allergy 2020;75(7):1742-1752

20 World Health Organization. Infection prevention and control during health care when COVID-19 is suspected. World Health Organization; 2020. Available at: https://www.who. int/publications-detail-redirect/10665-331495

21 World Health Organization. WHO Director-General's Opening Remarks at the Media Briefing on COVID-19. World Health Organization; 2020. Available at: https://www.who.int/ director-general/speeches/detail/who-director-general-sopening-remarks-at-the-media-briefing-on-covid-19---11march-2020

22 Shankar A, Saini D, Roy S, et al. Cancer care delivery challenges amidst coronavirus disease 19 (COVID-19) outbreak: specific precautions for cancer patients and cancer care providers to prevent spread. Asian Pac J Cancer Prev 2020;21(3):569-573 